\title{
FREQUENCY OF TWO ROOTS IN PERMANENT MANDIBULAR CANINE OF PAKISTANI POPULATION: A CONE BEAM COMPUTERIZED TOMOGRAPHY (CBCT) STUDY
}

\author{
Nauman Bari Khan ${ }^{a}$, Muhammad Azhar ${ }^{b}$, Nabeela Abassi ${ }^{c}$, Benish Mehmood ${ }^{\mathrm{d}}$ \\ ${ }^{a}$ Assistant Professor, Department of Oral Biology, Army Medical College, National University of Medical \\ Sciences, Rawalpindi, Pakistan. \\ ${ }^{\text {b}}$ Demonstrator, Department of Oral Biology, Army Medical College, National University of Medical Sciences, \\ Rawalpindi, Pakistan. \\ ${ }^{c}$ Assistant Professor, Department of Oral Biology, Rawal Institute of Health Sciences. \\ ${ }^{d}$ Associate Professor, Department of Community Medicine, Army Medical College, National University of \\ Medical Sciences, Rawalpindi, Pakistan.
}

\begin{abstract}
:
BACKGROUND \& OBJECTIVE: Missed root/canal is one of the main causes of endodontic failure. Permanent mandibular canine is considered to be a single rooted tooth. The complex pattern of root canal system poses difficulty in the root canal treatment and the prognosis becomes uncertain if the debridement and obturation of the root canals is not satisfactory therefore our objective of the study is to assess frequency of two roots in permanent mandibular canine of Pakistani population using CBCT scan.

METHODOLOGY: A descriptive; retrospective study was planned by using Cone Beam Computerized Tomography (CBCT) images of the past 02 year, i.e. December 2017 till November 2018. Images were assessed for the number of roots in permanent mandibular canines using software NNTVIEWER NewTOM. Data was entered and analyzed using SPSS 21.

RESULTS: 134 permanent mandibular canines of 67 patients were studied. $64.2 \%$ of the images were of male patients while $35.8 \%$ were of females. Mean age of the patients was $48.12 \pm 15.92$ years. $7(5.22 \%)$ out of 134 canines had two roots. 4 patients $(5.97 \%)$ had canines with 2 roots of which 3 patients $(4.48 \%)$ had bilateral two-rooted canines and 1 patient $(1.49 \%)$ had unilateral two-rooted canines. Frequency of two roots in mandibular canines had no association with gender $(p=0.127)$.
\end{abstract}

CONCLUSION: All mandibular permanent canines were single rooted but $5.2 \%$ of the permanent mandibular canines had two roots.

KEYWORDS: Cuspids, Root canals, Cone Beam Computerized Tomography (CBCT).

\section{How to cite this:}

doi: https://doi.org/10.37723/jumdc.v12i1.483

Khan NB, Azhar M, Abassi N, Mehmood B. FREQUENCY OF TWO ROOTS IN PERMANENT MANDIBULAR CANINE OF PAKISTANI POPULATION: A CONE BEAM COMPUTERIZED TOMOGRAPHY (CBCT) STUDY. jumdc. 2021;12(1):71-75.

doi: https://doi.org/10.37723/jumdc.v12i1.483

This is an Open Access article distributed under the terms of the Creative Commons Attribution License (http://creativecommons.org/licenses/by/4.0), which permits unrestricted use, distribution, and reproduction in any medium, provided the original work is properly cited. 


\section{INTRODUCTION:}

Permanent mandibular canines usually have a single, nearly straight, and the longest root in the mandibular arch. But occasionally variations are observed in its root pattern such as curved root or bifurcated roots with labial and lingual branches ${ }^{[1]}$. There is reported evidence of canines having a single root with two or three canals, two roots as well as fused roots. This is a recognized and documented fact that mandibular canines can have more than one root canal which clinicians should consider while performing quality endodontic treatment ${ }^{[2]}$. Few studies show that the existence of two canals and even more two roots is rare, ranging from $1 \%$ to $5 \%{ }^{[3]}$, whereas many other researchers reported that the occurrence of mandibular canines with one root and two roots is approximately $15 \%{ }^{[4,5]}$.

Complete knowledge of root morphology is essential for successful root canal treatment. The complex pattern of the root canal system poses difficulty in the endodontic treatment and the prognosis becomes uncertain if the debridement and obturation is not satisfactory ${ }^{[6]}$. If any root canal is left untreated, the infectious pulp tissue and bacteria may cause post-treatment disease, persistent apical periodontitis lesion or failure of endodontic treatment ${ }^{[7,8,9]}$.

Radiography is essential for diagnosis and treatment in endodontics but it has its limitations. A single radiograph is a twodimensional view of a three-dimensional object ${ }^{[7]}$. A radiograph identifies the presence and type of pathology, its location, the number of roots and canals, and any abnormal tooth anatomy (Dens in dente, dilaceration, high pulp horns etc.) ${ }^{[10]}$. Recently, new radiographic techniques have been developed to improve previous techniques as well as decrease the radiation dose to patients ${ }^{[7]}$. One such technique is cone beam computed tomography (CBCT), which is very accurate in producing three dimensional (3-D) images allowing more precise treatment planning. CBCT focused $\mathrm{x}$-ray decreases scatter radiation and results in improved quality image. It is very helpful in identifying morphological variations when conventional radiographic techniques fail to provide accurate information and more details are required ${ }^{[11]}$. Another
Corresponding Author:

Dr Nauman Bari Khan

Assistant Professor, Department of Oral Biology,

Army Medical College, National University of

Medical Sciences, Rawalpindi, Pakistan.

Email: nauman@gmail.com

advantage of CBCT is that it produces an image of bone as well as of soft tissue. The purpose of this study was to observe frequency of two roots in permanent mandibular canine in a Pakistani population through cone-beam computed tomographic (CBCT).

\section{METHODOLOGY:}

A retrospective study was carried out from 2017 to 2018 at Oral Radiology department of Armed Forces institute of dentistry (AFID), Rawalpindi. The consent was taken from the research ethical committee of AFID. The inclusion criteria of the study were Cone Beam Computed Tomography (CBCT) images with at least one mandibular permanent canine with fully matured root, without any pulp stone or calcification of the canals, without any filling or pathology of the apex. Artefacts, bad quality images and any non-Pakistani patients were excluded.

All patient records available in the database from year 2018 till 2019, and fulfilling the selection criteria, were included in the study. Roots of 134 canines were evaluated using the software NNTVIEWER NewTOM by two experienced examiners at the oral radiology department. The images were observed in coronal, axial and sagittal sections. $0.5 \mathrm{~mm}$ slicing was used for each image. Cross section and $3 D$ images were created to confirm the number of roots.

Roots were assessed on the axial plane by scrolling the plane. Crosssectional planes with a width of $30 \mathrm{~mm}$ and a thickness of $0.5 \mathrm{~mm}$ were used to inspect some scans more closely. SPSS 21 was used for data analysis. Mean and standard deviation was calculated for age of patients. Frequencies and percentages were calculated for the number of roots. Fisher's exact test was applied to compare qualitative variables between groups as the sample size was less and one cell in the stratification table had frequency of less than 5. $p$-value of less 
than or equal to 0.05 was considered as statistically significant.

\section{RESULTS:}

CBCT images of 67 patients were included in the study. All patients had mandibular canine intact hence the total number of 134 canines were assessed. $43(64.2 \%)$ of these patients were males while 24 (35.8\%) were females. Mean age of the patients was $48.12 \pm 15.92$ years. Out of 134 mandibular canines assessed 7 $(5.2 \%)$ had two roots (Figure-I A\&B). 4 patients $(5.97 \%)$ had canines with 2 roots of which 3 patients $(4.48 \%)$ had bilateral two-rooted canines and 1 patient $(1.49 \%)$ had unilateral two-rooted canine. Female patients had greater frequency of 2 roots as compared to male patients, but the difference was statistically insignificant $(p=0.127)$ (Table-I).

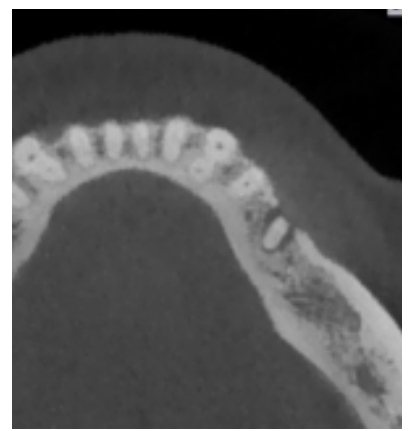

(A)

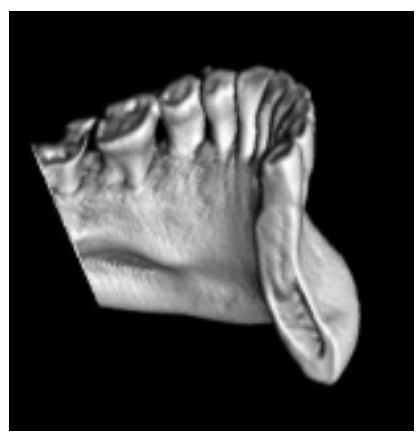

(B)
Figure-I: CBCT showing permanent mandibular canine with two roots.

Table-I: Stratification of number of roots in mandibular canine with gender.

\begin{tabular}{|c|c|c|c|c|}
\hline & & \multicolumn{2}{|c|}{$\begin{array}{l}\text { No. of Roots of Mandibular } \\
\text { Canine }\end{array}$} & \multirow{2}{*}{$\begin{array}{l}\text { Total no. of } \\
\text { canines }\end{array}$} \\
\hline & & Single Roots & Two Roots & \\
\hline \multirow{2}{*}{ Gender } & Male & $84(97.7 \%)$ & $2(2.3 \%)$ & $86(64.2 \%)$ \\
\hline & Female & $43(89.6 \%)$ & $5(10.4 \%)$ & $48(35.8 \%)$ \\
\hline \multicolumn{2}{|c|}{ Total No. of Canines } & $127(94.8 \%)$ & $7(5.2 \%)$ & 134 \\
\hline
\end{tabular}

\section{DISCUSSION:}

This retrospective study examined the frequency of two roots in mandibular permanent canines using "Cone Beam Computerized Tomography" CBCT. One of the most significant causes of endodontic therapy failure in teeth is the presence of a missed canal or an entire $\operatorname{root}^{[12]}$. The first step in any endodontic treatment is to acquire root anatomy understanding. Also, the clinician must review the radiographs taken from distinct perspectives before accessing the preparation of the cavity and also notice any sudden reduction or attenuation present.

It is necessary to evaluate the epidemiological character of each population and ethics. Knowledge and understanding of the root configuration can lead to increase in therapy success $^{[13]}$.

Various studies regarding internal and external dental anatomy showed that anatomical differences can happen in distinct ethnic communities in all groups of teeth with variable incidence.

In a study done in Iranian Population it was found that $12.08 \%$ out of 149 teeth have two roots ${ }^{[14]}$. While another study done in Serbian population found $5.8 \%$ had two roots ${ }^{[15]}$ Han et al. found $1.3 \%$ using CBCT method ${ }^{[16]}$. Zhengyan et al. with $0.8 \%$ and Soleymani et al. found $1.3 \%$ of population had two roots while using CBCT method ${ }^{[17,18]}$. A study done by Aminsobhani et al. found $4.7 \%$ of the population with two roots in mandibular canine ${ }^{[19]}$. In one of the studies done by Kandasamy, he found a rare variation in anatomy of permanent canine where he found three rooted canine tooth ${ }^{[20]}$. In our study it was found that $5.2 \%$ of the population had two roots. It was similar to the study done in Serbia where he found 5.8\% of the population had two roots. It was 
interesting to note that one patient had unilateral two roots while all other patients had bilateral two rooted mandibular canine. A larger sample size is needed to get more precise data in this region.

\section{CONCLUSION:}

All mandibular permanent canines were single rooted but $5.2 \%$ of the permanent mandibular canines had two roots.

\section{ACKNOWLEDGMENT:}

We would like to acknowledge the support of Radiology department at AFID, Rawalpindi

CONFLICT OF INTEREST: All authors disclose no conflict of interest.

\section{GRANT SUPPORT AND FINANCIAL DISCLOSURES: None}

\section{REFERENCES:}

1. Fuller JL, Denehy GE, Schulein TM. Concise Dental Anatomy and Morphology 4th Edition. Delhi: Arya Publications. 2010.

2. Almobarraz R. Endodontic retreatment of a mandibular canine with two roots and two canals. Journal of Pakistan Dental Association. 2019;28(2):98-100. Doi: 10.25301/JPDA.282.98

3. Plascencia H, Cruz Á, Gascón G, Ramírez B, Díaz M. Mandibular Canines with Two Roots and Two Root Canals: Case Report and Literature Review. Case Reports in Dentistry. 2017;8459840. Doi:10. 1155/2017/8459840

4. Pineda F, Kuttler $Y$. Mesiodistal and buccolingual roentgenographic investigation of 7,275 root canals. Oral Surgery Oral Medicine Oral Pathology Oral Radiology Journal 1972;33:101-110. Doi: 10.1016/0030-4220(72)90214-9

5. Ahmed HMA, Versiani MA, De-Deus G, Dummer PMH. A new system for classifying root and root canal morphology. International Endodontic Journal. 2017;50 (8):761-770. Doi: 10.1111/iej.12685

6. Darcey J, Roudsari RV, Jawad S, Taylor C, Hunter M. Modern endodontic principles part 5: obturation. Dental Update. 2016 ;43(2):114-129.

7. Torabinejad M, Walton RE. Endodontics Principles and Practice. Philadelphia: P Saunders: 2009. Doi: 10.12968/denu. 2016.43.2.114

8. Koç C, Sönmez G, Yilmaz F, Karahan S, Kamburoglu K. Comparison of the accuracy of periapical radiography with CBCT taken at 3 different voxel sizes in detecting simulated endodontic complications: an ex vivo study. Dentomaxillofacial Radiology. $2018 ; 22 ; 47(4): 20170399$. Doi : 10.1259/dmfr.20170399

9. Zhang X, Xiong S, Ma Y, Han T, Chen X, Wan $F$ et al. A Cone-Beam Computed Tomographic Study on Mandibular First Molars in a Chinese Subpopulation. PLoS One. 2015 4;10(8):e0134919. Doi: $10.1155 / 2017 / 8459840$

10. Chhabra A, Dogra A, Garg N, Bhatia R, Sharma S, Thakur S. Clinical and radiographic assessment of periapical pathology in single versus multi visit root canal treatment: An in vivo study. Journal of Conservative Dentistry . 2017;20(6): 429. Doi: $10.4103 / J C D . J C D \_87 \_17$.

11. Drage N. Cone Beam Computed Tomography (CBCT) in General Dental Practice. Primary Dental Journal. 2018;7(1):26-30. Doi: 10.1308/ 205016818822610316

12. Lo Giudice R, Nicita F, Puleio F, Alibrandi A, Cervino G, Lizio AS, et al. Accuracy of periapical radiography and CBCT in endodontic evaluation. International Journal of Dentistry. 2018:2514243. Doi: $10.1155 / 2018 / 2514243$

13. Lin L, Rosenberg P, Lin J. Do procedural errors cause endodontic treatment failure? Journal of American Dental Association. 2005; 136 (2):187-193. Doi: 10.14219/ jada.archive.2005.0140

14. Rahimi S, Milani AS, Shahi S, Sergiz Y, Nezafati S, Lotfi M. Prevalence of two root canals in human mandibular anterior teeth in an Iranian population. Indian Journal of Dentistry Research. 2013;24(2):234-236. Doi: 10.4103/0970-9290.116694

15. Popovic M, Papic M, Zivanovic S, Acovic A, Loncarevic S, Ristic V. Cone-beam computed tomography study of the root 
canal morphology of mandibular anterior teeth in Serbian population. Serbian Journal of Experimental and Clinical Research. 2018;19(1):27-34. Doi: 10.1515/SJECR.2017.0024

16. Han $T$, Ma $Y$, Yang $L$, Chen $X$, Zhang $X$, Wang $Y$. A study of the root canal morphology of mandibular anterior teeth using cone-beam computed tomography in a Chinese subpopulation. Journal of Endodontics. 2014;40(9):1309-1314. Doi: $10.1016 /$ j.joen.2014.05.008

17. Zhengyan Y, Keke L, Fei W, Yueheng L, Zhi $Z$. Cone-beam computed tomography study of the root and canal morphology of mandibular permanent anterior teeth in a Chongqing population. Therapeutics and Clinical Risk Management. 2015;23(12): 19-25. Doi: 10.2147/TCRM.S95657

18. Soleymani A, Namaryan N, Moudi E, Gholinia A. Root Canal Morphology of Mandibular Canine in an Iranian Population: A CBCT Assessment. Iranian Endodontic Journal. 2017;12(1):78-82.

19. Aminsobhani $M$, Sadegh $M$, Meraji N, Razmi $\mathrm{H}$, Kharazifard MJ. Evaluation of the root and canal morphology of mandibular permanent anterior teeth in an Iranian population by cone-beam computed tomography. Journal of Dentistry Tehran Iran. 2013;10(4):358-366.

20. Kandasamy S, Balakrishnan N, Chandrasekar M. A Three-Rooted Permanent Maxillary Canine: A Rare Anatomical Variant. Journal of Pharmacy and Bioallied Sciences. 2019;11(Suppl 2):S485-S487. Doi:10.4103/JPBS. JPBS_292_18

\section{Author's Contribution:}

Nauman Bari Khan: Conception, Design the study \& reference collection.

Muhammad Azhar: Data collection \& Analysis.

Nabeela Abassi: Drafting \& Editing.

Benish Mehmood: Reference Collection.

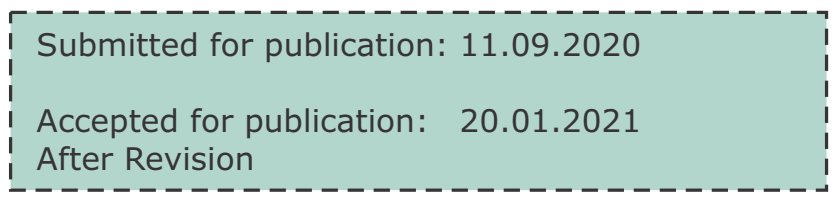

